\title{
Pharmacognostic Evaluation and Antimicrobial Activity of Root of Careya arborea
}

\author{
Bandenawaz Ramadurga ${ }^{1, *}$, Rakesh Kumar Jat ${ }^{2}$, Shrishailappa Badami ${ }^{3}$
}

\section{Bandenawaz Ramadurga ${ }^{1, *}$, Rakesh Kumar Jat ${ }^{2}$, Shrishailappa Badami ${ }^{3}$}

'Department of Biological Sciences, Baze University, Abuja, NIGERIA. ${ }^{2}$ Department of Pharmaceutical Sciences, JJT University, Chudela, Rajasthan, INDIA.

${ }^{3}$ Radiant Research Laboratories Pvt. Ltd., Bangalore, Karnataka, INDIA.

Correspondence

Mr. Bandenawaz Ramadurga

Department of Biological Sciences, Baze University, Abuja, NIGERIA.

E-mail: bandenawazramadurg@gmail.com History

- Submission Date: 12-09-2018;

- Review completed: 15-11-2018;

- Accepted Date: 07-02-2019

DOI : 10.5530/pj.2019.11.97

Article Available online

http://www.phcogj.com/v11/i3

Copyright

(C) 2019 Pharmacognosy Journal. This is an open-access article distributed under the terms of the Creative Commons Attribution 4.0 International license.

\begin{abstract}
Background: Careya arborea is known for its traditional medicinal properties and reported for potent antitumor, antioxidant, hepatoprotective and many other activities. Its stem bark, leaves and fruits were studied biologically, but so far its root has not been studied. Aim: The aim of the present study is to standardize the root of Careya arborea and its extracts pharmacognostically and also to screen its extracts for their antimicrobial activities against several bacteria and fungi using standard procedures. Materials and Methods: Loss on drying, extractive and ash values, fluorescence and phytochemical analysis of the root and its extracts were studied using standard procedures. Antimicrobial activity was carried out by determining minimum inhibitory concentration. Results: Among all the extracts, the successive ethyl acetate extract was found to be the most active with lowest MIC values against $L$. acidophilius, $S$. aureus, $C$. freundii, $P$. aeruginosa and $M$. luteus. The successive chloroform extract was also found to be highly active against $P$. aeruginosa and fungi, $M$. furfur and $C$. albicans. Conclusion: The results are helpful in standardizing the root of the plant and since several of the root extracts possess antimicrobial properties, there is a need to isolate its constituents. Key words: Careya arborea, Standardization, Antibacterial, Antifungal.
\end{abstract}

\section{INTRODUCTION}

Careya arborea Roxb. (family: Barringtoniaceae) is a handsome small to medium sized deciduous tree found in India sub Himalayan tract from Jammu eastwards to West Bengal, Madhya Pradesh, Tamilnadu, Karnataka, Sri Lanka and Andaman Islands. Most of its parts are of medicinal value. ${ }^{1}$ Its root is used in tuberculosis and skeletal fracture and in Ayurveda, bark and root are used in Vata and Kapha. ${ }^{2}$ Several steroids, saponins, flavonoids, tannins and alkaloids have been isolated from its various parts. ${ }^{1-7}$ Its CNS depressant, antidiarrheal, anticonvulsant, wound healing, gastroprotective, antioxidant, hepatoprotective, antitumor and other biological activities are well known. ${ }^{8,9}$ Antimicrobial activity of its fruits, ${ }^{10}$ leaves ${ }^{11}$ and stem bark extracts ${ }^{12}$ have been reported. Though the root is also used traditionally, so far it has not been studied biologically.

Antimicrobial resistance is presently a threat worldwide to human and animal health. The plant drugs, due to their diverse phytoconstituents and a wide variety of secondary metabolites derived from them, are useful as alternative strategies to control infectious diseases and to avoid resistance. ${ }^{13}$ Hence, in the present study we were interested in screening antimicrobial activity of root of Careya arborea. Along with this, to standardize the root and its extracts, pharmacognostic evaluation was also carried out.

\section{MATERIALS AND METHODS}

\section{Chemicals and Media}

Mueller Hinton broth, Brucella broth, Nutrient broth, Brain heart infusion broth and Sabouraud Chloramphenicol Agar were obtained from Micro Master Laboratories and resazurin dye and ciprofloxacin were obtained from Himedia, India. All other solvents and chemicals used were of standard grades.

\section{Collection, authentication and extraction}

The root of the plant Careya arborea was collected from Haridravati village, Hosanagar, Shimoga dist., Karnataka State, India in the month of March 2016. The plant was authenticated by Dr. S. Rajan, Survey of Medicinal Plants and Collection Unit, Ooty, Tamilnadu, India (voucher no.8570), where voucher specimens are preserved. The root was shade dried, powdered and Soxhlet extracted (300 g) with methanol (2.5 lts) for $12 \mathrm{~h}$. The extract was concentrated under reduced pressure at $50-60^{\circ} \mathrm{C}$ in a rotary evaporator, yielding a brown residue $59.25 \mathrm{~g}$, $19.75 \%$. The root powder was also extracted (350 g) in a Soxhlet apparatus successively with petroleum ether, chloroform, ethyl acetate and methanol (1.5 lts each) for $12 \mathrm{~h}$. The extracts were concentrated. Yields, successive petroleum ether extract, yellowish semisolid residue, $2.94 \mathrm{~g}, 0.84 \%$, chloroform extract,

Cite this article: Ramadurga B, Jat RK, Badami S. Pharmacognostic Evaluation and Antimicrobial Activity of Root of Careya arborea. Pharmacog J. 2019;11(3):608-12. 
yellowish brown solid, $1.47 \mathrm{~g}, 0.42 \%$, successive ethyl acetate extract, brown solid, $3.47 \mathrm{~g}, 0.99 \%$ and successive methanol extract, brown solid, $22.9 \mathrm{~g}, 6.54 \%$. The extracts were stored in a closed vessel at $4^{\circ} \mathrm{C}$ in a refrigerator till further use.

\section{Pharmacognostic evaluation}

The dried root powder of Careya arborea was used for pharmacognostic evaluations. Loss on drying, alcohol and water soluble extractive values and fluorescence analysis by treating the powder with various reagents and observing under ordinary light and UV light (long, $360 \mathrm{~nm}$ and short, $254 \mathrm{~nm}$ ) for possible color variations ${ }^{14,15}$ were determined. The extracts were also observed for their color variations under ordinary and ultraviolet rays. Ash values such as total ash, acid insoluble ash, watersoluble ash and sulfated ash were determined according to the Indian Pharmacopoeia. ${ }^{16}$ The extracts of Careya arborea were subjected to preliminary phytochemical screening for the detection of various plant constituents present using standard procedures. ${ }^{15}$

\section{Antimicrobial activity}

The crude methanol extract, successive petroleum ether, chloroform, ethyl acetate and methanol extracts were evaluated by MIC for antibacterial activity against $C$. freundii, E. coli, P. aeruginosa, S. aureus, L. acidophilus, $S$. marcescens and M. luteus and for antifungal activity against $C$. albicans, C. glabrata, C. krusei, M. furfur, A. niger, R. oryzae and Mucor sp at different concentrations. The MIC values of test substances were compared with the activity of standard antibiotic. Standard procedures were followed. ${ }^{17,18}$ The microbial strains and their sources are shown in Table 1.

\section{Antibacterial activity}

\section{Preparation and standardization of stock cultures}

A day prior to the experiment, a loopful culture of E. coli, P. aeruginosa, S. aureus, S. marcescens and M. luteus were grown in $\mathrm{NB}$ at $37^{\circ} \mathrm{C}$ for $24 \mathrm{~h}$. The culture of $L$. acidophilus, was grown on MHA. The cultures were adjusted to 0.17 absorbance at $600 \mathrm{~nm}$ (corresponding to approximately $10^{8} \mathrm{CFU} / \mathrm{ml}$ and $0.5 \mathrm{McF}$ arland Standard), using a spectrophotometer and further diluted to a concentration of approximately $10^{5} \mathrm{CFU} / \mathrm{ml}$.

\section{Preparation of resazurin and standard antibiotic solution}

The stock resazurin solution was prepared by dissolving $2.7 \mathrm{mg}$ in $4 \mathrm{ml}$ of sterile saline. Further, working solution was prepared by dissolving $1 \mathrm{ml}$ of stock solution in $5 \mathrm{ml}$ of sterile saline. The standard antibiotic i.e., ciprofloxacin solution at $1 \%$ concentration was prepared in sterile distilled water.

\section{Preparation of test samples}

Test samples crude methanol and successive petroleum ether, chloroform, ethyl acetate and methanol extracts were prepared at $10 \mathrm{mg} / \mathrm{ml}$ concentration by dissolving $10 \mathrm{mg}$ of test sample in $1 \mathrm{ml}$ of MHB. Sample were mixed using cyclomixer for $5 \mathrm{~min}$ and sonicated for 5-10 $\mathrm{min}$. Samples were mixed thoroughly before using for experiment.

\section{Determination of MIC}

Experiments were performed in triplicate under aseptic conditions. A volume of $50 \mu \mathrm{l}$ respective sterile MHB was added to all 96 wells except first three wells of the microtitre plate $\mathrm{A}_{1} \mathrm{~B}_{1} \mathrm{C}_{1}$ to which only $100 \mu \mathrm{l}$ test product was added. From first three wells $\left(\mathrm{A}_{1} \mathrm{~B}_{1} \mathrm{C}_{1}\right)$ of plate, $50 \mu \mathrm{l}$ of the test product was double diluted till $\mathrm{A}_{12} \mathrm{~B}_{12} \mathrm{C}_{12}$. To the wells containing test material $10 \mu \mathrm{l}$ bacterial suspension of approximately $10^{5} \mathrm{CFU} / \mathrm{ml}$ $\left(10^{6} \mathrm{CFU} / \mathrm{ml}\right.$ for S. mutans and L. acidophilus and P. acne) was added. A growth control (bacterial cell suspension $+50 \mu \mathrm{l}$ broth medium) from $\mathrm{G}_{1}$ to $\mathrm{G}_{12}$ and broth control (only broth medium $50 \mu \mathrm{l}$ ) from $\mathrm{H}_{1}$ to $\mathrm{H}_{12}$ was kept. A positive control that consists of ciprofloxacin was also placed in the plate. The plates were incubated at $37^{\circ} \mathrm{C}$ for $48 \mathrm{~h}$. After incubation, $10 \mu \mathrm{l}$ of working solution of resazurin was added to all wells. The plates were wrapped with aluminum film and incubated at $37^{\circ} \mathrm{C}$ for $1 \mathrm{~h}$. The color change was then assessed visually. Any color change from purple to pink or colorless was recorded as positive (growth). The lowest concentration at which there is no color change occurred was taken as the MIC value.

\section{Antifungal activity \\ Preparation and Standardization of Stock cultures}

C. albicans, C. glabrata, C. krusei, A. niger, R. oryzae and Mucor sp cultures were subcultured on SCA from glycerol stock. Plates of Candida

Table 1: Microbial strains and their sources.

\begin{tabular}{|c|c|c|c|c|}
\hline S. No. & Tested Strain & Strain No. & Equivalent No. & Source \\
\hline \multicolumn{5}{|c|}{ Bacteria } \\
\hline 1 & Citrobacter freundii & NCTC 9750 & ATCC 8090 & National Collection of Type Cultures, United Kingdom. \\
\hline 2 & Escherichia coli & NCTC 12923 & ATCC 8739 & National Collection of Type Cultures, United Kingdom. \\
\hline 3 & Pseudomonas aeruginosa & NCIM 2862 & ATCC 15442 & National Collection of Industrial Microorganisms, India. \\
\hline 4 & Staphylococcus aureus & NCTC 10788 & ATCC 6538 & National Collection of Type Cultures, UK \\
\hline 5 & Lactobacillus acidophilus & NCIM 2660 & - & National Collection of Industrial Microorganisms, India. \\
\hline 6 & Serratia marcescens & NCIM 2919 & - & -do- \\
\hline 7 & Micrococcus luteus & NCIM2103 & - & - do- \\
\hline \multicolumn{5}{|c|}{ Fungi } \\
\hline 8 & Candida albicans & NCPF 3179 & ATCC 10231 & National Collection of Pathogenic Fungi, UK \\
\hline 9 & Candida glabrata & MTCC 3019 & ATCC 90030 & Microbial Type Culture Collection, India \\
\hline 10 & Candida krusei & MTCC 9215 & - & -do- \\
\hline 11 & Malassezia furfur & $\operatorname{MTCC}^{*} 1374$ & - & - do- \\
\hline 12 & Aspergillus niger & NCPF 2275 & ATCC 16404 & National Collection of Pathogenic Fungi, UK \\
\hline 13 & Rhizopus oryzae & MTCC 262 & - & Microbial Type Culture Collection, India \\
\hline 14 & Mucor sp & MTCC 3340 & - & - do- \\
\hline
\end{tabular}


sp. were incubated at $28^{\circ} \mathrm{C}$ for $48 \mathrm{~h}$ and other fungi were incubated at room temperature $\left(30^{\circ} \mathrm{C}\right)$ for seven days. $M$. furfur was subcultured on Dixon's agar plate and incubated for 3 -days at $37^{\circ} \mathrm{C}$. In $10 \mathrm{ml}$ of sterile saline, a loopful of fungal conidia was dissolved and total numbers of conidia were adjusted to $10^{6} \mathrm{CFU} / \mathrm{ml}(0.5 \mathrm{McF}$ arland standards $)$ by counting under microscope using haemocytometer and fungal suspension was diluted in order to get $10^{3} \mathrm{CFU} / \mathrm{ml}$.

\section{Preparation of resazurin and standard antibiotic solution}

The stock resazurin solution was prepared as in antibacterial studies. The standard antibiotic i.e., ketoconazole solution at $1 \%$ concentration was prepared in sterile distilled water.

\section{Preparation of test samples}

Test samples, crude methanol, successive petroleum ether, chloroform, ethyl acetate and methanol extracts were prepared at $10 \mathrm{mg} / \mathrm{ml}$ concentration by dissolving $10 \mathrm{mg}$ of test sample in $1 \mathrm{ml}$ of MHB. Samples were mixed using cyclomixer for $5 \mathrm{~min}$ and sonicated for 5-10 min. Samples were mixed thoroughly before using for experiment.

\section{Determination of MIC}

Experiments were performed in triplicate under aseptic conditions. A volume of $50 \mu \mathrm{l}$ sterile RPMI was added to all 96 wells except first three wells of the microtitre plate $A_{1} B_{1} C_{1}$ to which only $100 \mu$ lest product was added. In first three wells $\left(\mathrm{A}_{1} \mathrm{~B}_{1} \mathrm{C}_{1}\right)$ of plate, $50 \mu \mathrm{l}$ of the test product was double diluted till $\mathrm{A}_{12} \mathrm{~B}_{12} \mathrm{C}_{12}$. To the wells containing test material $10 \mu \mathrm{l}$ conidial suspension of approximately $10^{3} \mathrm{CFU} / \mathrm{ml}$ was added. A growth control (bacterial cell suspension $+50 \mu \mathrm{l}$ broth medium) from $G_{1}$ to $G_{12}$ and broth control (only broth medium $50 \mu \mathrm{l}$ ) from $\mathrm{H}_{1}$ to $\mathrm{H}_{12}$ was kept. A positive control that consists of the ketoconazole (standard antibiotic) was placed in separate plate. The plates were then incubated at $28^{\circ} \mathrm{C}$ for $48 \mathrm{~h}$. MIC of $M$. furfur conducted in Dixon's broth and plates were incubated at $37^{\circ} \mathrm{C}$ for 3-4 days. After the incubation, $10 \mu \mathrm{l}$ of working solution of resazurin was added to all wells. The plates were wrapped with aluminum film and incubated for $1 \mathrm{~h}$. The color change was then assessed visually. Any color change from purple to pink or colorless was recorded as positive growth. The lowest concentration at which there is no color change occurred was taken as the MIC value.

\section{RESULTS}

\section{Pharmacognostic evaluation}

The moisture content, alcohol soluble and water soluble extractive values (average of three determinations) of the root of Careya arborea were found to be 5,13.6 and 12.8 percentages, respectively. The effects of both ordinary and ultraviolet lights on fluorescence properties of dried root powder and for extracts are recorded in Tables 2 and 3. The total, acid insoluble, water soluble and and sulphated ash values for the root powder of Careya arborea were found to be 2.5, 2, 2.33 and 2.5 (average of three determinations), respectively.

\section{Phytochemical analysis}

The qualitative phytochemical analysis showed the presence of carbohydrates, glycosides, saponins, flavonoids, phenolics, tannins, phytosterols and triterpenoids in the crude methanol extract. Flavonoids, phytosterols, triterpenoids, fixed oils and fats were present in the successive petroleum ether extract. Flavonoids, phytosterols and triterpenoids were present in the successive chloroform, Carbohydrates, glycosides and flavonoids in the successive ethyl acetate and Carbohydrates, glycosides, saponins, flavonoids, phenolics and tannins in the successive methanol extracts. The results from the above chemical tests are summarized in Table 4.
Table 2: Fluorescence analysis of the root powder of Careya arborea.

\begin{tabular}{|c|c|c|c|c|}
\hline \multirow{2}{*}{$\begin{array}{l}\text { SI. } \\
\text { No }\end{array}$} & \multirow{2}{*}{$\begin{array}{l}\text { Solvent added } \\
\text { to root powder }\end{array}$} & \multicolumn{3}{|c|}{ Observation* under } \\
\hline & & Ordinary & $\begin{array}{l}\text { UV Short } \\
\text { wave }\end{array}$ & $\begin{array}{l}\text { UV Long } \\
\text { wave }\end{array}$ \\
\hline & Distilled water & Orange & Green & Green \\
\hline & Chloroform & $\begin{array}{l}\text { Very light } \\
\text { yellow }\end{array}$ & Colorless & Colorless \\
\hline & $\begin{array}{l}1 \mathrm{~N} \mathrm{NaOH} \text { in } \\
\text { water }\end{array}$ & Dark brown & Dark brown & Dark brown \\
\hline & $\begin{array}{l}1 \mathrm{~N} \mathrm{NaOH} \text { in } \\
\text { methanol }\end{array}$ & Light yellow & Light green & Light green \\
\hline & $10 \% \mathrm{HCl}$ & Light orange & Light yellow & $\begin{array}{l}\text { Very light } \\
\text { green }\end{array}$ \\
\hline & $10 \% \mathrm{H}_{2} \mathrm{SO}_{4}$ & Light orange & Light yellow & $\begin{array}{l}\text { Very light } \\
\text { green }\end{array}$ \\
\hline
\end{tabular}

* The observation was based on three determinations

Table 3: Data showing the fluorescence analysis of different extracts of the root powder of Careya arborea.

\begin{tabular}{ccccc}
\hline \multirow{2}{*}{$\begin{array}{c}\text { SI. } \\
\text { No }\end{array}$} & Name of the & \multicolumn{3}{c}{ Observation* under } \\
\cline { 3 - 5 } & & $\begin{array}{c}\text { UV Short } \\
\text { wave }\end{array}$ & UV Long wave & Visible Light \\
\hline \multirow{3}{*}{$\begin{array}{c}\text { Successive } \\
\text { Petroleum ether }\end{array}$} & Brown & Greenish yellow & Yellow \\
Chloroform & Brown & Greenish brown & Light brown \\
Ethyl acetate & Dark brown & Greenish brown & Yellowish brown \\
Methanol & Dark brown & Dark black & Brown \\
Crude Methanol & Dark brown & Dark black & Brown \\
\hline
\end{tabular}

* The observation was based on three determinations".

\section{Antibacterial activity}

Among all the extracts, the successive ethyl acetate extract was found to be most active with lowest MIC values against $L$. acidophilius (MIC $31.25 \mu \mathrm{g}$ ), S. aureus (MIC $62.5 \mu \mathrm{g}$ ), C. freundii, P. aeruginosa and M. luteus (MIC $125 \mu \mathrm{g}$, Table 5). The successive chloroform extract was found to be highly active against $P$. aeruginosa with MIC value of $15.65 \mu \mathrm{g}$. The successive petroleum ether and crude methanol extracts have shown medium activity against $P$. aeruginosa with MIC value of $62.5 \mu \mathrm{g}$. The successive chloroform and methanol extracts have also shown medium activity against $C$. freundii and $P$. aeruginosa, respectively with MIC value of $125 \mu \mathrm{g}$. Except these, the extracts have shown low activity against the remaining organisms. However, the standard Ciprofloxacin was highly active when compared to all the extracts.

\section{Antifungal activity}

The successive chloroform extract of the plant Careya arborea root was found to be most active against $M$. furfur and C. albicans with MIC values of 31.25 and $62.5 \mu \mathrm{g}$, respectively (Table 6). The successive petroleum ether extract was also found to be active against these two organisms and C. krusei with MIC value of $62.5 \mu \mathrm{g}$. The successive ethyl acetate and methanol extracts and the crude methanol extract have also shown activity against $M$. furfur with MIC value of $62.5 \mu \mathrm{g}$. M. furfur was found to be the most susceptible to all the extracts. C. albicans was also found to be susceptible to all the extracts with MIC values ranging from 62.5 to $250 \mu \mathrm{g}$. A. niger was found to be the next susceptible with all the extracts except the successive methanol showing MIC value of 
Table 4: Preliminary Phytochemical tests for the root extract of Careya arborea.

\begin{tabular}{|c|c|c|c|c|c|c|}
\hline \multirow[b]{3}{*}{$\begin{array}{l}\text { SI. } \\
\text { No }\end{array}$} & \multirow[b]{3}{*}{ Test } & \multicolumn{5}{|c|}{ Extract } \\
\hline & & \multicolumn{2}{|c|}{ Crude } & \multicolumn{3}{|c|}{ Successive } \\
\hline & & 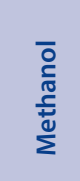 & $\begin{array}{l}\grave{\Xi} \\
\stackrel{ \pm}{ \pm} \\
\stackrel{ \pm}{\Delta} \\
\Delta\end{array}$ & $\begin{array}{l}\varepsilon \\
\frac{\xi}{0} \\
\frac{0}{0} \\
\frac{0}{U}\end{array}$ & 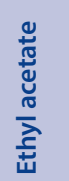 & 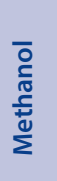 \\
\hline \multirow[t]{2}{*}{1} & Test for carbohydrates & & & & & \\
\hline & a. Molisch's test & + & - & - & + & + \\
\hline \multirow[t]{2}{*}{2} & Test for Glycosides & & & & & \\
\hline & Keller-Killiani test & + & - & - & + & + \\
\hline \multirow[t]{2}{*}{3} & Test for Saponins & & & & & \\
\hline & a. Foam test & + & - & - & - & + \\
\hline \multirow[t]{3}{*}{4} & Test for Alkaloids & & & & & \\
\hline & Mayer's test & - & - & - & - & - \\
\hline & Dragendroff's test & - & - & - & - & - \\
\hline \multirow[t]{2}{*}{5} & Test for Flavonoids & & & & & \\
\hline & Alkaline reagent test & + & + & + & + & + \\
\hline \multirow[t]{3}{*}{6} & $\begin{array}{c}\text { Test for Phenolics and } \\
\text { Tannins }\end{array}$ & & - & - & & \\
\hline & Ferric chloride test & + & - & - & - & + \\
\hline & Test for Tannins & + & & & - & + \\
\hline \multirow[t]{3}{*}{7} & $\begin{array}{l}\text { Test for Phytosterols and } \\
\text { Triterpenoids }\end{array}$ & & & & & \\
\hline & Leiberman-Burchard's test & + & + & + & - & - \\
\hline & Salkowaski test & + & + & + & - & - \\
\hline \multirow[t]{2}{*}{8} & Test for fixed oils and fats & & & & & \\
\hline & a. Oily spot test & - & + & - & - & - \\
\hline
\end{tabular}

(+) Present, (-) Absent, the observation was based on three determinations

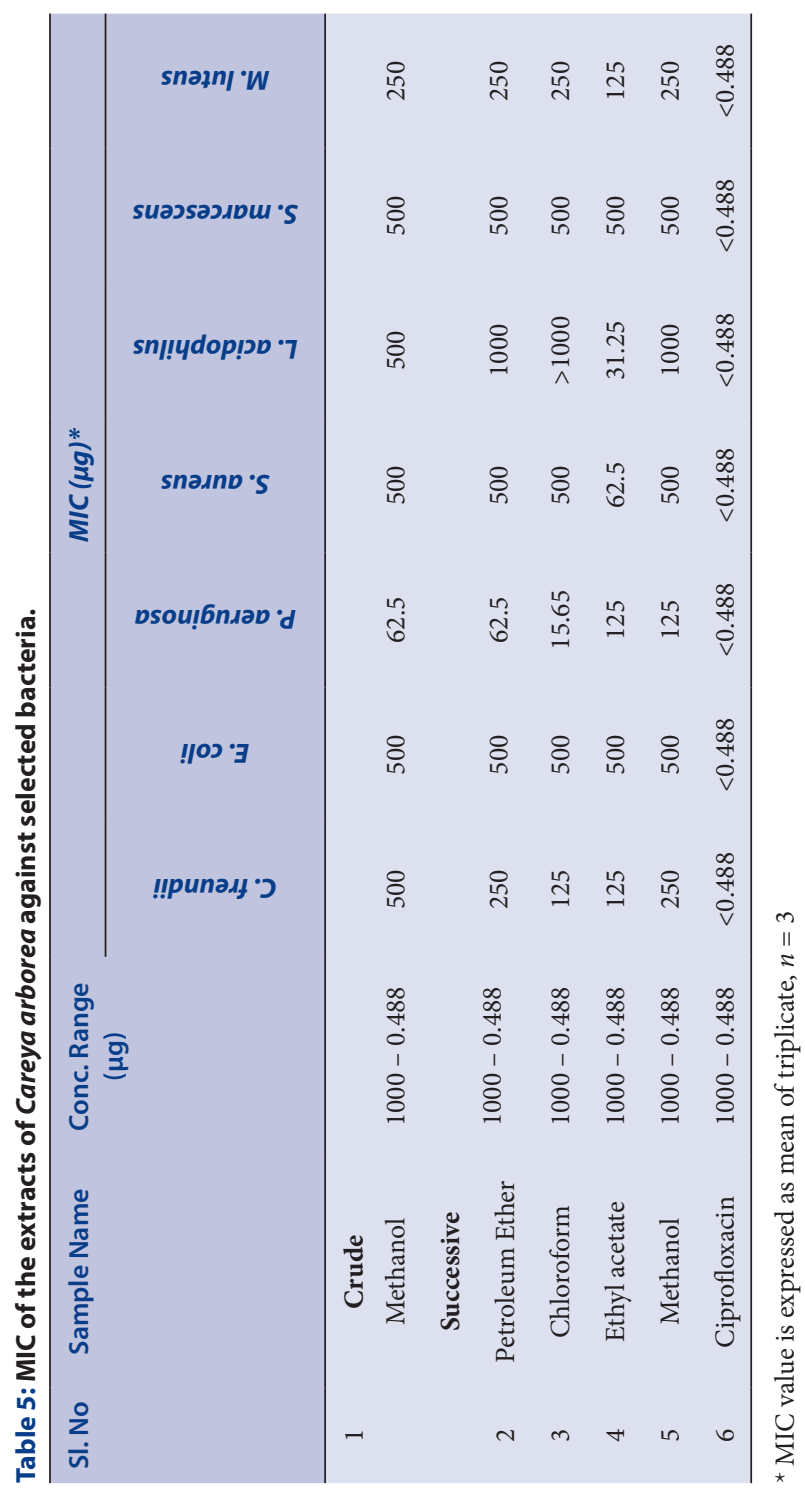

Table 6: MIC of the extracts of Careya arborea against selected fungi.

\begin{tabular}{|c|c|c|c|c|c|c|c|c|c|}
\hline \multirow{2}{*}{ SI. No. } & \multirow{2}{*}{ Sample Name } & \multirow{2}{*}{ Conc. Range $(\mu \mathrm{g})$} & \multicolumn{7}{|c|}{$\operatorname{MIC}(\mu \mathrm{g})^{*}$} \\
\hline & & & C. albicans & C. glabrata & C. krusei & M. furfur & A. niger & R. oryzae & Mucor sp. \\
\hline \multirow[t]{2}{*}{1} & Crude & & & & & & & & \\
\hline & Methanol & $1000-0.488$ & 125 & 250 & 250 & 62.5 & 125 & 125 & 125 \\
\hline \multicolumn{10}{|c|}{ Successive } \\
\hline 2 & Petroleum Ether & $1000-0.488$ & 62.5 & 500 & 62.5 & 62.5 & 125 & 250 & 250 \\
\hline 3 & Chloroform & $1000-0.488$ & 62.5 & 250 & 250 & 31.25 & 125 & $>1000$ & $>1000$ \\
\hline 4 & Ethyl Acetate & $1000-0.488$ & 250 & 125 & 125 & 62.5 & 125 & $>1000$ & $>1000$ \\
\hline 5 & Methanol & $1000-0.488$ & 125 & 500 & 250 & 62.5 & $>1000$ & 125 & 250 \\
\hline 6 & Ketoconazole & $1000-0.488$ & $<0.488$ & 0.976 & 0.976 & $<0.488$ & 15.62 & 15.62 & $<0.488$ \\
\hline
\end{tabular}

${ }^{*}$ MIC value is expressed as mean of triplicate, $n=3$ 
$125 \mu \mathrm{g}$. The crude methanol extract was found to be most active against all the organisms with MIC values ranging 62.5 to $250 \mu \mathrm{g}$. The successive methanol extract was also found to be active against all the organisms except $A$. niger and C. glabrata with MIC values of 62.5 to $250 \mu \mathrm{g}$. The ethyl acetate extract has shown activity against all the extracts except $R$. oryza and Mucor sp with MIC values of 62.5 to $250 \mu$ g. Except these, the extracts were found to be least active against the remaining organisms. However, the standard ketoconazole was highly active when compared to all the extracts.

\section{DISCUSSION}

Plants are untapped sources of chemotypes, used in many countries traditional medicine. The increasing incidence of drug resistant pathogens around the world has made the scientists to screen plant derived substances for antimicrobial activity. ${ }^{13}$ The plant Careya arborea is well known for its traditional biological used around the world, especially in India. Kumar et al. ${ }^{12}$ have tested the stem bark extract of the plant for antimicrobial activity and the extracts exhibited potent activity. Similarly the leaves extracts also exhibited the activity. ${ }^{10-11}$ Hence, in the present study, the antimicrobial activity of the root extracts was carried out. The successive ethyl acetate extract was found to be the most active against L. acidophilius, S. aureus, C. freundii, P. aeruginosa and M. luteus and the chloroform extract was found to be highly active against $P$. aeruginosa and fungi, M. furfur and C. albicans. Flavonoids, phytosterols and triterpenoids present in the successive chloroform extract and glycosides and flavonoids present in the successive ethyl acetate extract are responsible for the potent antimicrobial activity observed. Further studies are required to establish the same. The pharmacognositcal evaluation of the root and extracts carried out in the present study helps in establishing standards for the identification.

\section{CONCLUSION}

The results obtained in the present study are helpful in pharmacognostical standardization of the root of Careya arborea and several of its extracts exhibited potent antibacterial and antifungal activities, which are in concordance with the results obtained for the antimicrobial activity of its leaves and bark. ${ }^{10-12}$ Further studies are warranted to isolate its active constituents responsible for its antimicrobial activity.

\section{CONFLICT OF INTEREST}

The authors declare no conflict of interest.

\section{ABBREVIATIONS}

C: Centigrade; CFU: Colony Forming Units; CNS: Central Nervous System; h: Hour; MHA: Mueller Hinton Agar; MHB: Mueller Hinton Broth;
MIC: Minimum Inhibitory Concentration; NB: Nutrient Broth; RPMI: Roswell Park Memorial Institute Medium; SCA: Sabouraud Chloramphenicol Agar; UV: Ultra Violet.

\section{REFERENCES}

1. Kirtikar KR, Basu BD. Indian Medicinal Plants, $2^{\text {nd }}$ ed. Dehradun, India: Bishen Sing Mahendra Pal Sing. 1987;1061-3.

2. Yoganarasimhan SN. Medicinal Plants of India-Karnataka, Bangalore, India: Interline Publication. 1996.

3. Mahato SB, Dutta NL, Chakravarti RN. Triterpenes from Careya arborea: structure of Carreyagenol D. J Ind Chem Soc. 1973;50:254-9.

4. Ahmed M, Rahman MW, Rahman MT, Hossain CF. Analgesic principle from the bark of Careya arborea. Pharmazie. 2002;57(10):698-701.

5. Mahato SB, Banerjee SK, Chakravarti RN. Taraxerol from Careya arborea. Bull Calcutta Sch Trop Med. 1967;15(1):8-9

6. Mahato SB, Dutta NL. Sterols from Careya arborea. Phytochem. 1972;11:2116-7.

7. Talapatra B, Basak A, Talapatra SK. Terpenoids and related compounds. Part XX Careaborin, a new triterpene ester from the leaves of Careya arborea. J Indian Chem Soc. 1981;58:814-5.

8. Senthilkumar N, Badami S, Cherian MM, Hariharapura RC. Potent in vitro cytotoxic and antioxidant activity of Careya arborea bark extracts. Phytother Res. 2007;21(5):492-5.

9. Natesan S, Badami S, Dongre SH, Godavarthi A. Antitumor activity and antioxidant status of the methanol extract of Careya arborea bark against Dalton's lymphoma ascites-induced ascitic and solid tumor in mice. J Pharmacol Sci. 2007; 103(103):12-23.

10. Prabhakaran M, Reejo B, Suresh KD. Antibacterial activity of the fruits of Careya arborea Roxb. (Lecythidaceae). Hygeia JD Med. 2014;6(1):20-4.

11. Rathod SB, Hajare SW, Kukade SV, Rothe SP, Wadegaonkar PA. Studies on antitumor and antibacterial activities of Careya arborea Roxb. In vitro. Int J Pharma and Chem Sci. 2013;2:1746-51.

12. Kumar RS, Sivakumar T, Sundaram RS, Sivakumar P, Nethaji R, Gupta M Antimicrobial and antioxidant activities of Careya arborea Roxb. Stem bark. IJPT Iranian. 2006;5(1):35-41

13. Savola D. Plant derived antimicrobial compounds alternatives to antibiotics. Future Microbiol. 2012;7(8):979-90.

14. Chase CR, Pratt R. Flourescence of powdered vegetable drugs with particular reference to development of a system of identification. J Am Pharm Assoc. 1949;38(6):324-31.

15. Kokate CK, Purohit AP, Gokhale SB. Text Book of Pharmacognosy. $7^{\text {th }}$ Ed, Nirali Prakashan, Pune, India. 2001.

16. Anonymous, Indian Pharmacopoeia, $3^{\text {rd }}$ Ed., Controller of Publications, Govt. of India, New Delhi. 1985;2.

17. Satyajit DS, Lutfun N, Yashodharan K. Microtitre plate-based antibacterial assay incorporating resazurin as an indicator of cell growth and its application in the in vitro antibacterial screening of phytochemicals. Methods. 2007;42(4):321-4.

18. Anonymous, Methods for Dilution Antimicrobial Susceptibility Tests for Bacteria That Grow Aerobically; Approved Standard-Ninth Edition Approved standard M07-A9. Clinical and Laboratory Standards Institute, Wayne, PA, modified. 2012.

\section{GRAPHICAL ABSTRACT}

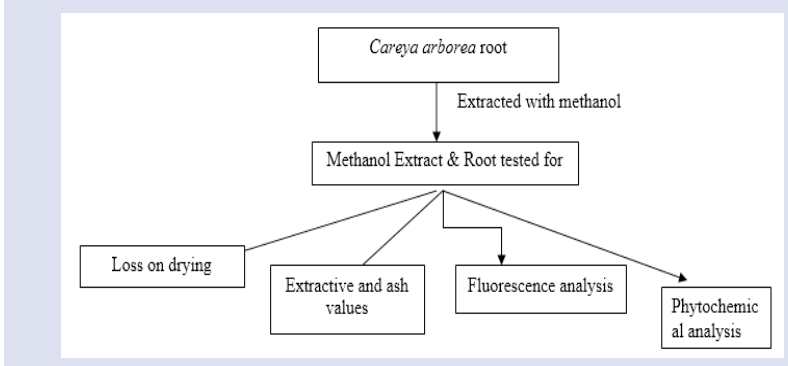

\section{SUMMARY}

- In the present study, Careya arborea root and its extracts were standardized pharmacognostically by determining Loss on drying, extractive and ash values, fluorescence and phytochemical analysis and its extracts were screened for their antimicrobial activities against several bacteria and fungi by determining minimum inhibitory concentrations.Among all the extracts, the successive ethyl acetate extract was found to be the most active with lowest MIC values against $L$. acidophilius, $S$. aureus, $C$. freundii, $P$. aeruginosa and $M$. luteus. The successive chloroform extract was also found to be highly active against $P$. aeruginosa and fungi, $M$. furfur and $C$. albicans.

Cite this article: Ramadurga B, Jat RK, Badami S. Pharmacognostic Evaluation and Antimicrobial Activity of Root of Careya arborea. Pharmacog J. 2019;11(3):608-12. 